\title{
The Implementation of Outsourcing System in Industrial Relation after the Constitutional Court Decision No. 27/PUU-IX/2011 in West Nusa Tenggara
}

\author{
Prof. Dr. H. Lalu Husni ${ }^{1}$ \\ Dr. Any Suryani Hamzah'1 \\ ${ }^{1}$ Lecturer of Faculty of Law, Mataram University, Indonesia
}

Doi:10.5901/mjss.2017.v8n3p109

\begin{abstract}
The present study is an empirical legal research which was conducted at the companies in West Nusa Tenggara. The data were obtained through legal reasoning which is logical, systematic and coherent and were analyzed using descriptive-analytic. Based on the analysis, the result showed that the implementation of outsourcing system in industrial relation after the Constitutional Court decision No. 27/PPU-IX/2011 on private companies in West Nusa Tenggara has not been done properly. The companies which became object of the study have understood that after the Constitutional Court Decision No. 27/PPUIX/2011, labor contract on outsourcing system has changed from PKWT (perjanjian kerja waktu tertentu/ labor contract for specific time) to PKWTT (perjanjian kerja waktu tidak tertentul labor contract for an unspecified time). In other words, the principle of labor protective measure transfer at companies might happen in case the company implements PKWT. However, the Constitutional Court Decision No. 27/PUU/IX/2011 which changed PKWT into PKWTT collides with Article 59 of Act No. 13 of 2003 on Manpower.
\end{abstract}

Keywords: Industrial relation, outsourcing system, constitutional court decision

\section{Introduction}

The role of labor in national development has a very strategic position both as the perpetrator and the purpose of the development. Therefore, national development, particularly manpower development, aims to optimally and humanely utilize labors, give protection to labors, and improve the welfare of labors and their families.

To strive for these goals, the government should participate as a party of the industrial relations by performing the function of deciding regulation and conducting investigation to the labor acts, so that industrial relations can work in harmony. As the result, productivity in industrial sector will increase and improve the welfare of labors and their families. Thus, manpower development must be able to create the conditions that allows the fulfillment of the rights and protections for labors and can create a conducive situation for developing the business sector.

Some of the regulations issued by the government in the field of manpower are Act No. 13 of 2003 on Manpower, Government Official Gazette of the Republic of Indonesia of 2003 No. 39, and the Supplementary of Government Official Gazette No. 4279. These laws are policy in the field of Manpower which present as the legal reform of the 6 (six) ordinance of Dutch Colonial and 9 (nine) laws that are considered no longer appropriate to the times. In addition to reform several old laws, Law Number 13 of 2003 on Manpower also sets a new issue of outsourcing.

In Bahasa Indonesia, outsourcing is known as "alih daya". There are several definitions of outsourcing. Maurice $F$ Greaver II (cited in Cahyo, 2006) defined outsourcing as "Strategic use of outside parties to perform activities, traditionally handled by internal staff and respurces". Another definition said that outsourcing is delegating the daily operation and management of a business process to outside parties (outsourcing company) (Suwondo, 2007). A similar opinion was also expressed by Muzni Tambusai, General Director of Industrial Relation of Department of Manpower and Transmigration, who defined outsourcing (alih daya) as put out one part or several parts of the companies' activities to contract which is previously managed independently by the company to another company which is called the recipient of work (Tambusai, 2005). 
The use of outsourcing system in industrial relation becomes a trend in business sector because competition in industrial world has the companies focus on a series of processes or activities to create products and services related to their main concern and competency. In this condition, the companies are able to focus on producing a number of well-qualified products and services in the market. In such conditions, the companies, of course, try to reduce their costs of production. One of the solutions is by outsourcing system, by which the system can save the financing of the company to pay the human resources working in the company (Wirawan, 2005). In this context, Gunarto Suhardi said with outsourcing system, the company does not necessarily spend much time and money find, select, and train the labors needed (Suhardi, 2008).

Stated in Act Number 13 of 2003 on Manpower, outsourcing can be said as the handover of some work implementation to other companies through an agreement of work contract or supplying labor service (Article 64). The requirements of implementing outsourcing system is then elaborated in Article 65 Paragraph 2 that outsourcing should be done separately from the main activities, be carried out with the direct or indirect orders from employers, be a supporting activities of the company, and not be directly disruptive to the production process. In addition, Article 65 paragraph 4 required "Protection of work and terms of employment for labors at least equal to protection of work and terms of employment in the company of employer or in accordance with current regulation". Industrial relation may also be based on labor contract for specific time or labor contract for an unspecified time referring to Article 59 of Act No. 13 of 2003 that only a temporary job (completion to three years) or seasonal work which can be made as labor contract for specific time. Besides, industrial relation between workers/laborers and the service provider of laborers/workers is needed (Article 66 paragraph $2 \mathrm{~b}$ ).

Seen from normative regulation above, it is clear that not all jobs can be carried out through outsourcing system, for outsourcing system is merely limited to the works supporting the production such as security services, cleaning services, transportation services, catering, and the like. In addition, the terms of employment are at least equal to what is in the company of employer or in accordance with current legislation. A harmonious industrial relation should also be built between labors and labor service provider. In other words, normatively outsourcing labors/workers has protected terms of employment supported with a predetermined verdict of the Constitutional Court No. 27 of 2011 stating that Article 65 paragraph 7 and Article 66 paragraph 2 of Act No. 13 of 2003 on Manpower do not have a binding legal force as long as labor contract does not apply the principle of protective measure transfer for labors who work in companies applying outsourcing system, though it occurs the replacement of the company who carry out some of work contract from another company or the provider company of labors.

However, outsourcing, in labors' point of view, is considered as a fairly frightening nightmare due to its uncertain continuity in industrial relation, for their contact may not be renewed or they are fired. Due to the nature of industrial relation which is not permanent, this may imply the absence of severance pay if the labors are fired. Therefore, through demonstration commemorating International Labor Day in many areas, including West Nusa Tenggara, on May 1, known as "May Day", the labors always demand to remove outsourcing system. In recent years in West Nusa Tenggara, the problem of outsourcing system becomes a heated discussion in newspapers and electronic mass media. For example, securities in Newmont Nusa Tenggara were doing a demonstration in several days at the representative office of Newmont in Mataram demanding the raise of salary and social guarantee. Conversely, Newmont was reluctant to fulfill the demand, for the securities were appointed through outsourcing company. Another demonstration addressed to the Department of Manpower and the Legislative Council of Mataram is done by securities of Mataram Mall and drivers of PT. Bank NTB complaining their uncertain future work as outsourcing workers (Lombok Post, April 2010).

Triggered by such phenomenon, this study endeavored to examine the real implementation of labor contract with outsourcing system after the Constitutional Court Decision No. 27/PUU-IX/2011. The specific objective to be achieved from this research is:

To know, understand, and analyze the real implementation of labor contract with outsourcing system after the Constitutional Court Decision No. 27/PUU-IX/2011;

The present study is based on the Constitution of the Republic of Indonesia of 1945 asserting that "everyone has the right to work and to receive remuneration and fair and proper treatment in employment (Article 28D paragraph 2). Based on a constitutional basis, it is clear that work is a fundamental right of everyone and every labor should not be treated arbitrarily, discriminatively, exploitatively, and other treatments demeaning them as human beings. To accomplish this aim, the government should participate in managing the problems of labor/employment through legal instrument to protect labors from the power of entrepreneurs as the consequence of substantive law state or welfare state which is embraced by the Indonesian people as mandated in state idée at the fourth paragraph of the preamble of the 1945 Constitution.

One of the laws issued by the government in order to reform the Labor Law is Act No. 13 of 2003 on Manpower. This Act governs the new issue of outsourcing (alih daya)/ handing over the work to other companies through a contract of work or labor service providers.

Although normatively Labor Law already provides sufficient protection for outsourcing labors, such as the terms of 
employment and rights and obligations for bot parties, in fact outsourcing is still deemed as a terrifying nightmare for labors. For that reason, it is necessary to profoundly examine the implementation of outsourcing system to find out why outsourcing labors/workers with have not received fair treatment as specified in the current legislation.

\section{Research Methods}

The research is a normative legal research that examines and analyzes legislation, legal principles, and legal norms in order to obtain clear description of the legal aspects of the implementation of industrial relation with outsourcing system after the Constitutional Court Decision. Despite it is a normative research, this research is also supported by field data (empirical).

\section{Results and Discussion}

\subsection{An Understanding of Outsourcing and Its Implementation in West Nusa Tenggara}

Outsourcing or "alih daya" is a quite new vocabulary in business sector coined since the 1990s (Indrajit and Djokopranoto, 2004). Nowadays outsourcing is a system of work that is commonly used in domestic public company and private company. Maurice Greaver (cited in Faiz 2007) mentioned that outsourcing is the act of diverting some of the activities and the decision of the company to outside provider, in which the act is bound in a joint contract. Some experts and practitioners of outsourcing in Indonesia said that outsourcing, known in Bahasa Indonesia as "alih daya", is delegating the daily operation and management of a business process to outside parties (Outsourcing Service Company). Meanwhile, Faiz (2007) defined outsourcing as contracting one part or several parts of the companies' activities which were previously managed by the companies to another company named as the recipient of work. From the variety of these definitions it can be concluded that in outsourcing there is a handover of some activities of the company to other parties. Besides, it can be interpreted as the presence of third party between employers and labors that is the labor provider.

Outsourcing system, in the opinion of the owners of capital, is the most efficient way to reduce costs of production since they have less or even no cost for employee benefits. Outsourcing systems is solely applied on side jobs such as security, catering, and cleaning service. The reasons of companies to apply outsourcing system are;

a. Increasing the company's focus on the main production activities;

b. Utilizing the capabilities of outsourcing providers or manpower providers that are considered to have advantage in each field;

c. Accelerating profits;

d. Dividing the risk of the company;

e. Using the sources for other needs that bring in advantage;

f. Allowing the availability of more capital fund for main businesses;

g. Creating fresh funds through the delivery or sale of assets that were previously used for non-main-business activities;

h. Reducing and controlling operating costs;

i. Obtaining the resources that are not owned by the company;

j. Solving problems that are difficult to control. (Indrajit and Djokopranoto, 2004)

Based on the results of research conducted at several companies in West Nusa Tenggara, it showed that generally the companies have known the Constitutional Court Decision Number 27/PPU-IX/2011 on Outsourcing. Nevertheless, the companies stated the contract period is running. Therefore, if they implement the Constitutional Court Decision Number 27/PPU-IX/2011, it contradicts the principle of non-retroactive. This is clearly illustrated by the results of interviews with several companies which became the samples below:

a. PT. Kinaya, located on jalan Pejanggik, is a labor service provider (outsourcing company) and a limited liability company (Ltd.). It has a license from the responsible agency in the field of manpower and has 8 (eight) employees work at Astra International which is located in Dasan Cermen. The company has understood that, according to Constitutional Court Decision No. 27/PUU-IX/2011, outsourcing labor contract has changed from PKWT into PKWTT. Due to the presence of the principle of laborer protective measure transfer at companies (in case the company implements PKWT), new company should continue the contract created by previous outsourcing company. Jobs submitted to outsourcing company in accordance with Article 65 of Law No. 13 of 2003 have been implemented by the company after fulfilling these requirements, which are:

1) The implementation is separated from the main activity;

2) The implementation is based on direct or indirect command from the employer; 
3) The job is a supporting activity of the enterprise;

4) The job is not a direct intervention of production process.

b. PT. Sri Chandra Dwipa, located on jalan Sadewa No. 15a Banjar Mantri Cakranegara, is a labor service provider and a limited liability company (LTd.). It has a license from the responsible agency in the field of manpower with approximately 50 employees working at several partner companies such as Hotel 51 resort, LPMP of West Nusa Tenggara province, PT. Tamarin Jaya, CV. Jembatan Baru, MIRASA Bakery, PT. Muda Muara Damai, PT. Catur Santosa Adiprana, PT. Utama Beton Perkasa, and PD. BPR NTB Mataram. By understanding the Constitutional Court decision No. 27/PUU-IX/2011, the company knew that outsourcing labor contract has changed from PKWT to PKWTT which is clarified by the Act No. 13/2003 that the rights of workers must be noticed. The company knows that by the presence of the principle of labor protective measure transfer at companies implementing PKWT, if new company continues the contract that has been created by previous outsourcing company, the workers are placed in other partner companies. Industrial relation between labors and labor service Provider Company should also be built. Jobs submitted to outsourcing company, according to Article 65 of Law No. 13 of 2003, were clearly based on the standardized rules and met the qualifications. However, labor contract that applies in industrial relation between labor service provider and labors complies with the provisions of Article 59 of Act No. 13 of 2003 on Manpower explaining that PKWT can solely be made for work which can be completed in specified time. The protection of welfare and working conditions as well as disputes that might arise become the responsibility of the labor service provider by seeing and following the rules in the contract (interview with I Made Dwipa SH., director of PT. Sri Chandra Dwipa, on May 12, 2015, on jalan Sadewa No. 15 a Cakranegara).

c. PT. Suli Sri Lestari, located at jalan Sadewa No. 15 a Cakranegara, is a labor service provider and a limited liability company (LTd.). It has a license from the responsible agency in the field of manpower and employs 10 workers at several partner companies such as BPTP of West Nusa Tenggara (cleaners), PT. Narmada Awet Muda (supervisor and driver), and PT. Sumber Cipta Multiniaga (distributors of commodities). In understanding of the Constitutional Court Decision No. 27/PUU-IX/2011, the company has known that labor contract of outsourcing has changed from PKWT into PKWTT. With the principle of labor protective measure transfer at companies, the new company should continue the contract that has been created by previous outsourcing company but has not been applied by the present company. Jobs submitted to outsourcing company, according to Article 65 of Law No. 13 of 2003, were clearly based on the standard rules and met the qualifications. Meanwhile, the labor contract that applies in industrial relation between labor services provider and the labors complies with the provisions of Article 59 of Act No. 13 of 2003 on Manpower explaining that PKWT can solely be made for work which can be completed in specified time. The protection of welfare and working conditions as well as disputes which might arise become the responsibility of the labor service provider by seeing and following the rules in the contract (interview with Ni Luh Sulita M, SH, Directress of PT. Sri Suli Lestari, on May 13, 2015, at Cakranegara).

d. PT. Prasmindo Inti Boga Utama is company engaged in catering and a limited liability company (LTd.). It has a license from the responsible agency in the field of manpower and employs 393 workers at several partner companies such as PT. Newmont Nusa Tenggara. In understanding of the Constitutional Court Decision No. 27/PUU-IX/2011, the company has known that outsourcing labor contract has changed from PKWT into PKWTT. And with the principle of labor protective measure transfer at companies, the new company should continue the contract that has been created by previous outsourcing company but has not been applied by the present company. Jobs submitted to outsourcing company, according to Article 65 of Law No. 13 of 2003, were clearly based on the standardized rules and met the qualifications. Meanwhile, the labor agreement that applies in industrial relation between labor service provider company and labors complies with the provisions of Article 59 of Act No. 13 of 2003 on Manpower explaining that PKWT can solely be made for work which can be completed in specified time. The protection of welfare and working conditions as well as disputes which might arise becomes the responsibility of the labor service provider by seeing and following the rules in the contract. After finishing the contract for five years, some workers are discharged and given an amount of severance pay based on the laws, while some of them have extended the contract based on the need of the company (interview with the HRD Manager of PT. Prasmindo Boga Inti Utama, on June 12, 2015).

If the Constitutional Court Decision No. 27/PUU-IX/2011 contradicts to what is mentioned in Article 59 of Act No. 13 of 2003 on Manpower, PKWT cannot be changed into PKWTT due to its nature which is temporary, seasonal, new product introductions, and activities in courtship. Supposedly, the Constitutional Court Decision No. 27/PPU-IX/2011 should make the works stated in Article 59 of Law No. 13 of 2003 as an Article that has been excluded by the verdict. In 
other words, PKWT clearly cannot be changed into PKWTT.

\subsection{Principles of Labor Protective Measure Transfer}

Outsourcing system exists as the result of work specialization. Through work specialization, the implementation of outsourcing system will be easy since the differences between main businesses and supporting businesses can be seen clearly. Work specialization, said Braverman Ritzer (2007), involves the division of job or operation into small and very specialized parts, each of which is mandated to different workers. The reasons of capital owner to enforce the work specialization are:

a. Increasing management control, for work specializations facilitate a company in organizing and controlling labors;

b. Improving productivity;

c. Allowing the owners of capital to pay the lowest wages for the labors needed.

After the work specialization is made, the policy of using outsourcing system emerges due to some reasons, such as efficiency, capital, and improvement of quality and quantity of production. This is in line with the opinion of Mr. Hartato, HRD of PT. Newmont Nusa Tenggara Sumbawa Regency in the interview on June 25, 2015 stating that outsourcing system will reduce the burden of companies on income and protection for workers' health because it is already managed by labor provider company.

Outsourcing system, formerly known as sub-contract, has been long applied in Indonesia since the release of the Minister of Trade Decision No. 264/KP/1989 on Sub-Contract Works for Processing Companies in Bonded Zones, which is affirmed by the Decree of the Minister of Trade 135/KP/NI1993 on Import and Export of Goods to and from Bonded Zone (Saptorini and Suryomenggolo, 2005). This decision is addressed to garment companies in bonded area, by the reasons that the nature of the industry focusing on the export market. Therefore, they are allowed to give some manufacturing processes to other companies. In addition, it is also intended to cut production costs and production time to pursue the demand of export market. Thus, outsourcing system in Indonesia was initially limited to a specific production model which was solely for the benefit of the export market. The Policy of outsourcing systems is included in the trade and industrial policies.

Outsourcing system began to become labor policy through the Letter of the Minister of Manpower No. SE/08/MEN/1990 on the Responsibility of Work Contract Provider Company for the Protection and Welfare of Workers of Contractor Company. The emergence of this letter was caused by the striking difference about the protection and welfare of workers in companies in the labor contractor company. This incompatibility was solved by giving the responsibility for the protection and welfare of workers in the labor contractor to the employer.

However, it is considered too burdensome for the employers because generally they are foreign investors. These complaints were taken through the Regulation of Minister of Manpower No. Per-02/Men/1993 on Job Agreements for Specific Time. This rule changes the character of the contractor law from individual to legal entities, especially foundations and cooperation. It is intended to shift the responsibility towards the workers from the employer to the contractor. Therefore, since that time the protection and welfare of workers are the responsibility of the contractors where workers take shelter.

According to Act No. 13 of 2003 on Manpower, working system with outsourcing becomes more controlled. Basically this Act continues the existing policy by eliminating some restrictions made. Article 65 of 2003 on Manpower adopted rules of Decree of the Minister of Trade No. 135/KP/VI/1993 on Import and Export of goods to and from Bonded Zone. Article 65 of 2013 on Manpower set that the "delivery some of work implementations to other companies" must be made in writing and "shall be separately conducted from the main activities". What makes Article 65 different is it does not contain detailed restrictions as mentioned in the Decree of the Minister of Trade, in which the employer company should:

a. not have difficulty in achieving production targets;

b. be limited to certain industrial sectors;

c. have limitation of working time;

d. only be carried out by companies operating in the limited bonded area;

e. produce products which are not marketed in the country and only intended for the export market;

Thus, Article 65 of Act No. 13 of 2003 on Manpower is not too binding and removes all restrictions that are made by the Minister of Trade of Indonesia in 1993. Generally, the delivery of work to other companies which becomes sample in the study (PT. Pramsindo Boga Inti, PT. Sri Suli Lestari, PT. Sri Chandra Dwipa, PT. Kinaya) has been carried out in writing and separated from the main activities. In the Act, it is stated the obligations to establish labor service Provider Company. It means that there is a diversion from a working contractor company into labor Provider Company. In this case, it seems the 
workers are used as a commodity by the labor provider company. In addition, the Act states that outsourcing system is suitable for any companies, throughout the territory of Indonesia and not limited to bonded zones only.

\subsection{Industrial relation between labors and labor provider company}

Labor condition in Indonesia is very vulnerable at this time, full of uncertainty, and threatened into layoffs. Layoff decision could occur because the companies do not accept an order from overseas buyers or get miss-management that leads into bankruptcy. This situation is affected by the legalization of outsourcing system and labor contract system. These work systems are getting widely used by the capital owners. The data indicated that approximately $60-70 \%$ of workers are contract and outsourcing workers. Several reasons are said by the owners of capital who use the systems, such as saving the costs which should be used as allowances for permanent employees such as health funds, bonus received near holidays, severance, and maternity leave for women. The reason of the government issuing Act No. 13 of 2003 on Manpower is to reduce the high number of unemployment.

Before a company introduces outsourcing system agreements, there are two stages to be followed: firstly, the agreement should be made between the company and the employer with the labor provider company containing the terms of jobs that will be outsourced. According to Article 65, paragraph 2 of Act No.13/2003 on Manpower, jobs that will be outsourced must fulfill requirements, such as:

a. be done separately from the main activity;

b. be done in accordance with the direct or indirect orders from the employer

c. be a supporting activity of the company

d. not inhibit the production process

Secondly, the agreement between labor and labor provider that regulates the terms of providing labor is in accordance with Article 66, paragraph 2 of Act No.13/2003 on Manpower are:

1) There is industrial relation between labor and labor provider;

2) Labor contract for a specific time that applies in industrial relation that meets the requirements and/or labor contract for an unspecified time should be made in writing and be signed by both parties;

3) Protection and welfare, working conditions or disputes become the responsibility of labor provider.

This is confirmed by the results of interviews with the director of PT. Sri Chandra Dwipa on May 12, 2015, located on jalan Banjar Sadewa No. 15 A Banjar Mantri Cakra Negara Mataram, stating that the rights of outsourcing labor will be the responsibility of labor provider company.

Labors who work daily in Employer Company are the employee of labor provider company. Therefore, all the rights and issues related to the labors are the responsibility of the labor provider company. The contract between labor and labor Provider Company depends on how long it has been agreed by the employer and provider. In the Articles stated above, there is no trouble for outsourcing labors because theoretically their rights will be met by the provider company. However, practically there are many deviations committed by the Employer Company and Provider Company toward outsourcing system. For example:

a. The employer company does not comply with the conditions that have been set for the type of jobs that are outsourced, for example PT. Mitshuba Indonesia in Tangerang that hires outsourced workers as production operator.

b. In addition, they also break the working time limitation that has been set for labors. Under Article 59 paragraph 1 item 2, jobs on specific time should not exceed 3 years, but many companies continue to extend the time without lifting the labors into permanent employees (Asi, 2003).

c. The labor contract has been made unilaterally or without the agreement, the workers was not told the content of agreements, and the majority of workers are not given the health facility, food money and overtime money. These conditions are not in accordance with the Labor Law No.13/2003.

The Deviations are already common, but labors cannot do much to complain because they have to keep working in order to get the money for their needs. This is what Marx called as alienation, in which a worker cannot live like human beings who can continuously improve their own prosperity, for they are chained to the level of animal life because they cannot be separated from the need to defend life from day to day (Kusumandaru, 2004).

In outsourcing system, labors become a commodity because they are sold by the labor provider to the buyer of labor (employer company) covered by the "agreement" that since the beginning did not stand up for workers' welfare. In this work system, the condition of workers is more difficult than usual because they do not have certain job. Anytime they can be laid off without severance pay even though they have worked for long enough. In addition, they also do not get medical benefits and leave or holiday for any reason. Not working means salary reductions. 
This is illustrated by the agreement made between the employer company and labor provider company. There is no provision accommodating the interests of labor related to severance and health benefits of the employer company. For example, the labor contract for specific time at PT. Suli Sri Lestari as labor Provider Company only contains the following provisions:

a. The identities of the parties;

b. Industrial relation;

c. Duration of the agreement;

d. Job placement;

e. Rotation;

f. Work time and shift;

g. Income;

h. Risk/compensation;

i. Welfare;

j. Domicile;

k. Dispute resolution.

\subsection{Protection of salary and welfare and working conditions}

The impact of outsourcing system is enormously appalling. In this system, labors will never get the opportunity for a promotion of position because they work in the required time by company. For example, a company needs outsourcing labors for specific jobs within a certain time. When the work is completed, these workers will be easily laid off and recruited back when they are needed. In fact, many companies require workers to do a particular job by using the system because they do not want to lose a lot of capital for labor or labor benefits. It means labors will never get the opportunity to raise the level of welfare.

The practice of outsourcing has created fragmentation or grouping among workers based on employment status at the company level. Practically, there are three groups of workers in one factory, which are permanent workers, contract workers, and outsourcing workers. These groupings are generally marked with a different color uniforms worn by the three groups of the workers. Grouping by color of uniforms carries the effects of stratification and social distance between permanent workers and outsourcing workers which has implications on solidarity and collective consciousness as a laborer.

The practice of outsourcing relationships brings in at least three forms of discrimination against workers, namely:

a. Age and Marital Status Discrimination

The policies adopted by the company to hire outsourcing labors include age restriction and marital status, in which it unconsciously raises a discriminatory effect. The companies tend to hire young workers and require new outsourcing labors aged 18-24 years old and single status for productivity reasons. Choosing single workers bears more difficulty for workers who have a family to get a job and income.

b. Salary Discrimination

Outsourcing labors who do the same job in the same working hours with permanent workers receive different salary. The total salary of contract workers is $17 \%$ lower than the salary of permanent workers and the total salary of outsourcing labors is $26 \%$ lower than the salary of permanent workers.

c. Associative Discrimination

Contract and outsourcing labors are prohibited to directly or indirectly join a particular union and may not be extended if joining a union. The practice of outsourcing takes the effect of degradation or deterioration in the working conditions and welfare of workers. In industrial relation, the workers do not get job guarantee because they have one year contract in average, only get the minimum salary and receive some allowances smaller than what is received by permanent workers, must pay for recruitment work to extend the term of the contract, get no compensation when the industrial relation ends, and receive small status and career improvement opportunities.

Outsourcing practices also tend to be exploitative because in doing the same job contract worker and outsourcing worker receive different salary and rights and some workers have to pay to get a job or to keep their job. If, based on these studies, the outsourcing application can give a negative impact on society; on the other hand, it provides benefits to the government, such as: (1) developing and encouraging economic growth and national economic growth; (2) constructing and developing the activities of cooperation and small and medium enterprises. The benefits of outsourcing to the community include: (1) stimulating economic activity in the community support; (2) developing social infrastructure of society, fostering good working culture and discipline, and increasing economic capacity; (3) reducing unemployment 
and (4) improving the capacity and effort of society.

For that reason, the Constitutional Court finally makes corrections to the article related to outsourcing in the Act on Manpower which determines to: Article 65 paragraph 7 and Article 66 paragraph 2 of Act No. 13 Year 2003 on Manpower. These articles do not have a binding legal force as long as the labor contract do not apply the principle of protective measure transfer for labors who work at outsourcing companies despite the replacement of contractor or labor provider company.

However, labors keep considering outsourcing as a very frightening specter because it is lack of certain continuity in industrial relation. This phenomenon might imply for the absence of severance pay in layoffs due to the absence of permanent industrial relation. This is quite reasonable because it is based on the result of interviews with Boediono, President Director of PT. Prasmindo Boga Inti Utama as labor service provider, conducted on June 12, 2015. He stated that workers are contracted for five years and after that they are laid off and given severance pay in accordance with the legislation. Some of the contracts are renewed in accordance with company requirements. It means that normatively all of responsibilities related to labors become responsibility of the main companies that recruit, especially related to the term of agreement that was contrary to the provisions of Article 59 paragraph (1) of the Act on Manpower which requires a maximum of 3 years of work.

Based on the legal effectiveness theory, the implementation of the law is determined by the suitability of the material with social dynamics where the law is enforced. Soekanto (1992) argued that the law can purpose well if the harmony of several factors exist, such as legal factors, law enforcement apparatus, means or facility, community, and culture.

The implementation of the Act on Manpower is caused by law enforcement apparatus factor who had been directly involved in law enforcement such as police, prosecutors, and judges. In addition, it is also known institution of labor agency supervision handled by civil servant investigator as stipulated in Law No. 23 of 1948 jo. Law No. 3 of 1951 on the Labor Supervision. A limited number of labor supervisions have affected the implementation of the Labor Law and the Constitutional Court Decision, in particular related to the outsourcing.

\section{Conclusion}

The Implementation of outsourcing system in industrial relation after the Constitutional Court Decision No. 27/PPUIX/2011 on private companies in West Nusa Tenggara has not been done properly. The sample companies have understood that after the Constitutional Court Decision No. 27/PPU-IX/2011, labor contract with outsourcing system has changed from PKWT to PKWTT. In other words, the principle of labor protective measure transfer at companies might happen in case the company implements PKWT. Therefore, the new company must continue the contract that was made by the previous company. Nevertheless, the substance of the Constitutional Court Decision has not been implemented properly. The Constitutional Court Decision No. 27/PUU-IX/2011 contradicts to what is mentioned in Article 59 of Act No. 13 of 2003 on Manpower. As the result, PKWT cannot be changed into PKWTT due to its nature which is temporary, seasonal, new product introductions, and activities in courtship. Supposedly, the Constitutional Court Decision No. 27/PPU-IX/2011 should make the works stated in Article 59 of Law No. 13 of 2003 as an Article that has been excluded by the verdict. In other words, PKWT clearly cannot be changed into PKWTT.

\section{References}

Cahyo, N. (2006). Transfer of Employment Supporting companies with System Outsourcing (Outsourcing) According to Law No. 132003 On Employment (Case Study on Asuransi Astra Buana). Thesis. Faculty of Law, University of Indonesia. Depok.

Faiz, M. (2007). Outsourcing (Outsourcing) and Power Management in Company. (http://www.panmohanad faiz.com [accessed on October 5,2008$]$.

Indrajit, RE. and Djokopranoto, R. (2004). Business Process Outsourcing. Jakarta: PT. Gramedia Widiasarana Indonesia. Kusumandaru, KB. (2004). Karl Marx, Revolution and Socialism: Rebuttal to Franz Magnis Suseno. Magelang: Resist Book.

Ritzer, G and Douglas J.G. (2007). Modern Sociological Theory. Kencana Predana Media Group, Jakarta.

Saptorini, I. and Suryomenggolo, J. (2005). Social Power of Trade Unions: New Round in the Struggle Refuse Outsourcing. Jakarta: Trade Union Right

Suhardi, G. (2008). Legal Protection for Outsourcing Contract Workers. Atma Jaya University, Yogyakarta.

Suwondo, C. (2007). Outsourcing; Implementation in Indonesia. Elex Media Computindo. Jakarta.

Tambusai, M. (2005). Implementation Outsourcing (Outsourcing) Judging from the Legal Aspects of Employment Not Blurring of Industrial Relations. http://www. nakertrans.go.id/arsip berita/naker/outsourcing.php, [accessed on May 29, 2010]

Wirawan. (2005). Binoculars Law Sections. What is the outsourcing system? http://www.pikiran-rakyat.com/cetak/0504/31 /teropong/komenhukum.htm, [accessed on June, 2010]. 